\title{
Evaluation of Tobacco Control Law at Cafe' and Restaurants
}

\author{
Hilal Özcebe ${ }^{1}$, Burcu Küçük Biçer ${ }^{1}$, Nazmi Bilir ${ }^{1}$, Sema Attila², \\ Hakan Doğruel², Burçin Kaya², Mahmut Cesur², Betül Bıçakçı², Tan Ayık², \\ Semaye Türk², Mehmet Ali Harbelioğlu²
}

${ }^{1}$ Institute of Public Health, Hacettepe University Faculty of Medicine, Ankara

${ }^{2}$ Department of Public Health, Hacettepe University Faculty of Medicine, Ankara

\begin{abstract}
Objective: This study was conducted in order to evaluate ideas of some cafe and restaurants' clients and workers about the tobacco control law three years after entering into force in a central district in Ankara in 2008.

Methods: In the descriptive study; 105 management, 113 worker and 386 client was visited, face to face interviews were done using two different questionnaire form and another form for managements' evaluation. SPSS 15.0 statistical package program, Chi-square and t-tests were used. Administrative leave was taken.

Results: Mean age of workers was $30.1 \pm 8.32$ years; $82.3 \%$ were men, $54.0 \%$ smoker; with clients the values are $27.7 \pm 8.61$ years; $53.6 \%$ women and 39.4\% were smokers. There's a difference between smokers and non- smokers' ideas about the hazards; death due to second-hand smoking $(\mathrm{p}=0.024 ; \mathrm{p}<0.01) .80 .3 \%$ of smokers and $74.3 \%$ of non-smokers knew the law in restaurants serving alcoholic beverages. Acceptance of the idea of the law could help to quit smoking was significantly different between smoker/non smoker workers and smoker/non smoker clients $(\mathrm{p}=0.004 ; \mathrm{p}<0.001)$. According to observations, $7.6 \%$ of the managements didn't have law related plaque, $94.1 \%$ had smoking free areas, $57.1 \%$ had show window, $22.7 \%$ had smoking individuals and $12.6 \%$ had ashtray.

Conclusion: Tobacco use is an individualistic reality but also a public health issue. Publicly acceptance of 45 law and implementations are needed besides individual perceptions. Implementations must be inspected and Smokers' observance of the rules must be supplied in order to decrease tobacco use and related health complications.
\end{abstract}

Keywords: Cafe, law, management, restaurant, tobacco

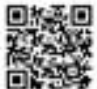

Received Date: 19.07.2013

Accepted Date: 12.01 .2015

Available Online Date: 27.02 .2015

Address for correspondence

Burcu Küçük Biçer, Institute of Public Health,

Hacettepe University Faculty of Medicine,

Ankara, Turkey

E-mail: drburcubicer@gmail.com

This work is licensed under a Creative Commons Attribution-NonCommercia 4.0 International License.

DOI: 10.5152/ejp.2015.70037

- Available online at www.eurasianjpulmonol.com

\section{INTRODUCTION}

Globally, tobacco use is a major health concern. It is known that approximately 1.5 billion people smoke around the world. Approximately 6 million people die in a year as a result of tobacco use, which is the most important preventable cause of mortality, and in 2030, this number is predicted to increase to 10 million $(1,2)$.The use of tobacco products is decreasing in developed countries, while it is increasing in developing countries. Globally, more than $80 \%$ tobacco users live in underdeveloped and developing countries.

The health problems associated with tobacco are not only limited to those using these products but also to the health of those around tobacco users is influenced negatively. Therefore, tobacco control studies aim to protect the health of both active and passive smokers. One of the main approaches for protecting the health of people not using tobacco is preventing tobacco use indoors. Along with the prevention of smoking indoors, educational activities on passive smoke exposure and the enforcements by the law are also important. For these laws to be successfully implemented, people using and those not using tobacco should possess an awareness regarding the harmful effects of passive smoke exposure, and they are expected to have the skill level to exercise their legal rights $(2,3)$.

In Turkey, the studies on tobacco control were first initiated by the Ministry of Health in late 1980s and accelerated with the studies of the Turkish National Committee on Tobacco and Health (SSUK) that assembled all public and non-governmental organizations under a single roof to fight against smok- 
ing in 1995. In 1996, the law on tobacco control numbered 4207 on the Prevention of Hazards of Tobacco Products was enacted with the government's help. In order to prevent passive smoke exposure with this law, the use of tobacco was banned in health and educational institutions, places where sports and cultural activities were performed, public transportation vehicles, and places where 5 and more people work. The Framework Convention on Tobacco Control (FCTC), a globally significant step toward tobacco control, includes an important intervention clause for the prevention of the effects of secondhand smoke. In accordance with this convention, countries promise to protect the society against passive smoke exposure. This convention was also signed by our country and it came into effect after being accepted by the Grand National Assembly of Turkey (GNAT) in 2004 (2). With the implementation of the law numbered 4207, which is considered to be a milestone for tobacco control in Turkey and was enacted in 1996, public acceptance has been achieved for the ban of tobacco use in some closed areas. As a benefit of this positive approach, the scope of the law was extended in 2008 and tobacco use was forbidden in all closed areas including catering sector businesses such as restaurants, pubs, and cafes $(4,5)$. This implementation was initially not accepted, however, over time, it was adopted both by the society and business owners (6).

In this study, we aimed to evaluate the knowledge, opinions, and attitudes of some cafe and restaurant managers, workers, and clients, regarding the tobacco control law and its implementation three years after the law coming into effect in the central county of Ankara.

\section{METHODS}

This descriptive study was conducted in the districts of Bahçelievler and Kızılay in the county of Çankaya, Ankara. The participants of the study consisted of the clients, workers, and managers of some cafes and restaurants, in the districts of Bahçelievler and Kızılay. In the businesses where the study would be conducted, the owners or managers were informed regarding the purpose of the study at the beginning and their consent was obtained for the survey. In additon, before each questionnaire was administered, the participants were informed. The ones who accepted to participate in the study were included. Workers and clients of 50 cafes and restaurants on the 3rd and 7th streets in the district of Bahçelievler and 55 cafes and restaurants on Konur Street, Karanfil Street, and Selanik Street in the district of Kızılay were included in the study. Of the businesses visited, $68.1 \%$ were cafes and patisseries and $31.9 \%$ were restaurants. As a result, interviews were performed in totally 105 businesses.

In order to collect data, two questionnaire forms were developed. The first one was for cafe/restaurant owners/managers, workers, and clients. This form included 31 questions regarding sociodemographic features, smoking behavior, and knowledge and opinions regarding the law. The data were obtained from clients and workers through face-to-face interviews and noted in forms by the interviewer. The second data collection form was collected through a business observation form and it included questions about the physical features of cafes and restaurants and their legality. This form was completed by the researchers.

While planning the study, administrative permission was obtained from the Governorship of Ankara, in accordance with the recommen- dations of the ethics committee. In the study based on voluntariness, verbal consents of the participants were obtained before data collection.

\section{Statistical Analysis}

The data were analyzed using SPSS (Statistical Package for Social Sciences) 15.0 statistical software (SPSS, Chicago, IL, USA). Chi-square and T-tests were employed for descriptive statistics.

\section{RESULTS}

In the district of Bahçelievler, totally 211 ( 25 workers/owners/managers and 186 clients) people from 50 cafes and restaurants on the $3^{\text {rd }}$ and $7^{\text {th }}$ streets were interviewed. In the district of Kızılay, 55 cafes and restaurants on Konur, Karanfil, and Selanik Streets were visited and 200 clients and 88 workers and business owners were interviewed. Of the businesses visited, $68.1 \%$ were cafes and patisseries and $31.9 \%$ were restaurants. As a result, totally 499 people (386 clients and 113 business owners and workers) were interviewed in 105 businesses.

The mean age of workers was $30.1 \pm 8.32$ years and the mean age of clients was $27.7 \pm 8.61$ years. Half the workers $(47.8 \%)$ were in the age group of $25-44$ years and half the clients (47.9\%) were in the age group of 18-24 years. Approximately $53.6 \%$ clients were female and $82.3 \%$ of workers were male; $45.3 \%$ of participants were university students and $39.1 \%$ of these students were clients and $52.2 \%$ of workers and $69.4 \%$ clients were married. And $70.5 \%$ of workers stated that they worked in this sector for more than 4 years (Table 1).

With regard to cigarette use, $54 \%$ of workers and $39.4 \%$ of clients stated that they smoked. One-fifth of workers (21.3\%) and one-tenth of clients (11.2\%) had smoked for more than 16 years. About $18 \%$ of workers and $9.9 \%$ of clients mentioned that they smoked more than one pack per day. It was found that participants smoked frequently at home, in balconies, in their private cars, and on the street. More than half the workers $(55.7 \%)$ and $39.5 \%$ of clients stated that they did not ask for permission from people around them for smoking (Table 2).

Of workers who smoked, $70.5 \%$ stated that smoking could lead to mild health problems, $37.7 \%$ stated that it could cause serious health problems, and $11.5 \%$ stated that it could cause death (Table 3 ). While no difference was found between workers smoking and not smoking with regard to the thoughts on health problems associated with passive smoke exposure, there was a difference between clients smoking and not smoking $(p=0.024)$. Clients who did not smoke stated that second-hand smoking would lead to more health problems, which was statistically significant.

Among clients who had quit smoking, the rate of clients with the thought that smoking caused serious health problems was higher than among those clients who were still smoking and those who had never smoked. However, the rate of clients with the thought that smoking caused mild health problems was lower $(p<0.001)$. Conversely, compared to other groups, particularly clients who had never smoked, thought that smoking could cause death.

In addition, $99.5 \%$ smokers and $97.3 \%$ non-smokers knew that smoking in public institutions was forbidden, and $80.3 \%$ smokers and $74.3 \%$ non-smokers stated that smoking was banned in restaurants 
Table 1. Distribution of sociodemographic features of workers and clients in cafes/restaurants in the districts of Bahçelievler and Kızılay in the county of Çankaya (June, 2012)

\begin{tabular}{|c|c|c|c|c|}
\hline Sociodemographic features & \multicolumn{2}{|c|}{ Worker $(n=113)$} & \multicolumn{2}{|c|}{ Client $(n=386)$} \\
\hline \multicolumn{5}{|l|}{ Age groups (years) } \\
\hline $18-24$ & 30 & 26.5 & 185 & 47.9 \\
\hline $25-34$ & 54 & 47.8 & 130 & 33.7 \\
\hline Male & 93 & 82.3 & 179 & 46.4 \\
\hline Female & 20 & 17.7 & 207 & 53.6 \\
\hline \multicolumn{5}{|l|}{ Educational status } \\
\hline Primary school graduate & 4 & 3.5 & - & - \\
\hline University graduate & 19 & 16.8 & 151 & 42.2 \\
\hline *University student & 7 & 6.2 & 163 & 39.1 \\
\hline \multicolumn{5}{|l|}{ Marital status } \\
\hline Married & 59 & 52.2 & 268 & 69.4 \\
\hline Single & 48 & 42.5 & 101 & 26.2 \\
\hline Divorced & 6 & 5.3 & 17 & 4.4 \\
\hline \multicolumn{5}{|l|}{ Working status** } \\
\hline Yes & & & 155 & 40.3 \\
\hline$\geq 11$ & 19 & 17.0 & & \\
\hline
\end{tabular}

where alcoholic beverages were served (Table 4). The rate of smokers' approval of this law was lower in smokers than in than non-smokers. In terms of the ban on smoking in restaurants with window walls, the rates were similar among those who smoked, did not smoke and those who quit.

Workers who were smokers/non-smokers and most of the clients agreed with the opinion that the law reserved the right of clean air for non-smokers.

Workers/clients who smoked generally disagreed that the law helped smoking cessation and limited the right of smoking for clients. They agreed that the law protected the health of workers in restaurants and cafes; however, no statistically significant difference was observed in the distribution.
Non-smoking workers/clients thought that this law would decrease the use of tobacco, increase the rate of smoking cessation, and protect the health of workers and they also thought that it would not restrict the right of smoking for clients. The values were statistically significant (Table 5).

The opinions of non-smoking clients and workers were mostly similar. Their agreement that the law would help quitting smoking was higher compared to the clients and workers who smoked $(71.2 \%$, $76.9 \%)$. This difference was found to be statistically significant between smoking and non-smoking workers and also between smoking and non-smoking clients $(p=0.004 ; p=0.000)$.

Based on the observations of researchers, it was detected that $7.6 \%$ of businesses did not have a warning sign related to the law, 94.1\% 
Table 2. Smoking behavior of workers and clients in cafes and restaurants, in the districts of Bahçelievler and Kızılay, Çankaya (June, 2012)

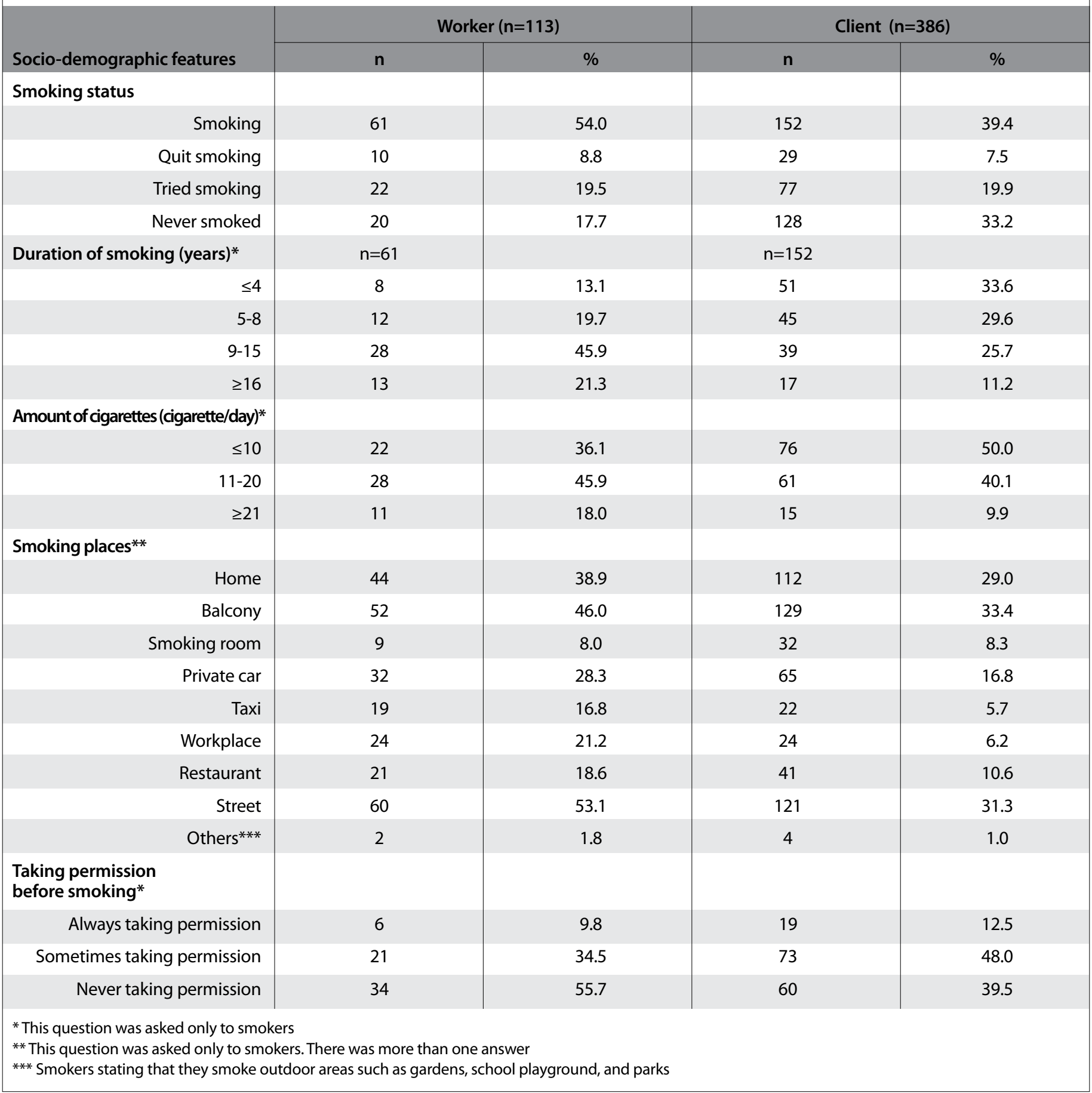

had a designated smoking area, $57.1 \%$ had an area closed with window walls and there were smokers in $227 \%$ of them, $12.6 \%$ had ashtrays, $15.1 \%$ had the smell of cigarette smoke, and $0.8 \%$ had a playing machine with a cigarette as the award.

\section{DISCUSSION}

It has been proven that the use of tobacco products cause many diseases, particularly cancer, heart, and lung diseases. For preventing tobacco-induced diseases, restriction of smoking indoors is one of the most important interventions. However, public approval and acceptance plays an important role in the successful implementation of these laws. Therefore, knowing the opinions and understanding the attitudes of workers and clients, particularly in the catering sector, periodically is important. This study aimed to evaluate the opinions and attitudes regarding the law on the ban of tobacco use in the catering sector, by interviewing the owners/managers, workers, and clients of some cafes and restaurants in the districts of Bahçelievler and Kızılay in Ankara.

When sociodemographic features of clients who participated in the study were evaluated, it was seen that most of them were in the young age group. This might have been a result of the region's fea- 
Table 3. In cafes and restaurants of the districts of Bahçelievler and Kızılay, knowledge of workers and clients regarding the health problems caused by second-hand smoking (June, 2012)

\begin{tabular}{|c|c|c|c|c|c|c|c|}
\hline \multirow[b]{2}{*}{ Health problems } & \multicolumn{7}{|c|}{ According to smoking status } \\
\hline & n & $\%$ & n & $\%$ & $\mathbf{n}$ & $\%$ & $\mathrm{p}$ \\
\hline Worker $(n=113)$ & $(n=61)$ & & $(n=32)$ & & $(n=20)$ & & \\
\hline No health problems & 6 & 9.8 & - & - & 1 & 5.0 & - \\
\hline Death & 7 & 11.5 & 2 & 6.3 & 2 & 10.0 & - \\
\hline Clients ( $n=386)$ & $(n=152)$ & & $(n=106)$ & & $(n=128)$ & & \\
\hline No health problems & 13 & 8.6 & 2 & 1.9 & - & - & - \\
\hline Mild diseases* & 93 & 61.2 & 48 & 45.3 & 77 & 60.2 & 0.024 \\
\hline
\end{tabular}

Table 4. In cafes and restaurants of the districts of Bahçelievler and Kızılay, the percentage distribution of workers' and clients' knowledge, regarding the ban on smoking indoors, and their opinions regarding approval of the law (June, 2012)

\begin{tabular}{|c|c|c|c|c|c|c|c|c|c|}
\hline \multirow[b]{2}{*}{ Indoor areas } & \multicolumn{4}{|c|}{$\begin{array}{l}\text { Knowledge on the ban } \\
\text { according to smoking status }\end{array}$} & \multirow[b]{2}{*}{$\mathbf{p}$} & \multicolumn{4}{|c|}{$\begin{array}{c}\text { Approval of the law according } \\
\text { to smoking status }\end{array}$} \\
\hline & $\mathrm{n}^{*}$ & $\begin{array}{l}\text { Smoking } \\
(n=100)\end{array}$ & $\begin{array}{l}\text { Having } \\
\text { quitted } \\
(n=49)\end{array}$ & $\begin{array}{l}\text { Non- } \\
\text { smoking } \\
(\mathrm{n}=62)\end{array}$ & & $n^{* *}$ & $\begin{array}{c}\text { Smoking } \\
(n=100)\end{array}$ & $\begin{array}{l}\text { Having } \\
\text { quitted } \\
(n=49)\end{array}$ & $\begin{array}{l}\text { Non- } \\
\text { smoking } \\
(\mathrm{n}=62)\end{array}$ \\
\hline Patisserie & 493 & 98.6 & 98.6 & 99.3 & - & 210 & 75.7 & 93.4 & 97.3 \\
\hline Cafe & 484 & 95.8 & 97.1 & 98.6 & - & 381 & 58.8 & 91.8 & 94.5 \\
\hline Restaurant & 493 & 99.5 & 97.8 & 98.6 & - & 412 & 68.4 & 92.6 & 97.3 \\
\hline Restaurant closed with glass walls & 142 & 66.2 & 65.9 & 67.6 & 0.573 & 449 & 87.0 & 96.2 & 97.2 \\
\hline Restaurant serving alcoholic beverages & 397 & 80.3 & 84.1 & 74.3 & 0.011 & 212 & 27.5 & 66.4 & 80.0 \\
\hline Taxi & 440 & 87.3 & 90.6 & 87.2 & 0.566 & 372 & 71.5 & 91.2 & 96.9 \\
\hline Public transportation & 485 & 97.7 & 96.4 & 97.3 & - & 198 & 95.9 & 100.0 & 96.7 \\
\hline Public institution & 493 & 99.5 & 99.3 & 97.3 & - & 452 & 84.9 & 96.4 & 97.2 \\
\hline \multicolumn{10}{|c|}{$\begin{array}{l}\text { *The number of people stating the smoking ban } \\
\text { **This question was asked to people who stated that smoking was banned } \\
\text { The significance value was } 0.05 \text { for } p \text { value }\end{array}$} \\
\hline
\end{tabular}

tures where the study was conducted. In Ankara, cafes and restaurants in are frequently visited by the young. Young people meeting in these places might have caused this distribution.

During the study, 39.4\% clients and more than half the workers stated that they still smoked cigarettes (Table 2). According to the Global Adult Tobacco Survey Report, the frequency of smoking under the age of 15 years is $31.2 \%(29.9 \%-32.5 \%)(7)$. The same research revealed the rate of smoking cessation to be higher than in our study [15.9\% (15.0-16.9)] (7.8\% in workers, 9.4\% in clients). In the Global Adult Tobacco Survey Report (8), the rate of smoking is $27.0 \%$ and the rate of trying to quit smoking is $35.4 \%$. The high rate of tobacco use in this study might have resulted from the higher number of young people in this group. The studies conducted in our country show that the frequency of tobacco use among young people is higher than the frequency in the total population. This rate is high in many other countries. For instance, a study conducted in university students in Jordan found that the frequency of smoking in the last 30 days to be $29 \%$ (9). In another study performed in the United States of America, majority of which comprised female university students, $25.8 \%$ stated that they still smoked (10).

It was found that the workers interviewed in this study smoked for a long time and the number of cigarettes they smoked per day was 
Table 5. In cafes and restaurants in the districts of Bahçelievler and Kızılay, percentage distribution of the opinions of workers and clients on some statements related to the smoking ban indoors (June, 2012)

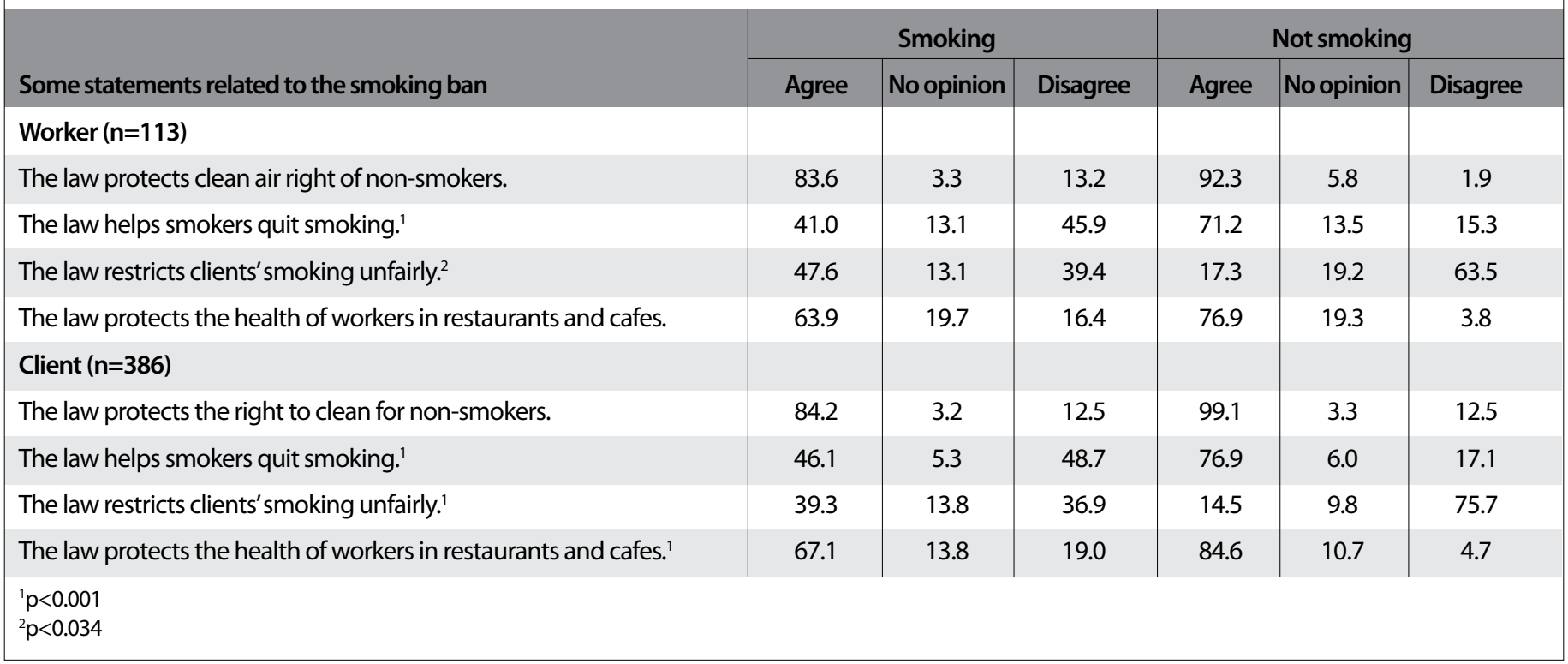

quite high. It is believed that the possibility of diseases occurrence associated with passive smoke exposure in workers in these businesses will increase because they smoke and also are exposed to tobacco smoke.

The smoking behaviors and sociodemographic features of workers and clients interviewed in the businesses were varied. It is believed that the smoking behaviors of people affect their opinions regarding the law; therefore, it is important to interpret data and opinions regarding smoking behaviors.

A statistically significant difference was found between smoking and non-smoking clients with regard to their knowledge of the health problems caused by secondhand smoke $(p<0.05)$ (Table 3$)$. Nonsmoking clients had more knowledge regarding the harmful effects of smoking. This result may be explained by the fact that smokers do not have a realistic approach toward the harmful effects of smoking. In the Global Adult Tobacco Survey, the rate of knowledge regarding the harmful effects of tobacco is higher than $90 \%$ (11). The attempt to quit smoking in some group members might have been a result of educational activities and campaigns performed for the group. From positive point of view, the rate of smoking cessation can be increased by providing smokers' with the awareness of the health problems associated to smoking and their acceptance regarding the same.

In this study, people in these businesses were also asked questions regarding the scope of this law. Nearly all smokers and non-smokers knew that smoking was forbidden in patisseries, cafes, restaurants, public transportation, and public institutions. However, the rate of knowledge regarding the ban on smoking in restaurants serving alcoholic beverages, restaurants with closed glass walls, and taxis was lower. Moreover, there was a statistically significant difference between smokers and non-smokers in terms of knowing the ban on smoking in restaurants serving alcoholic beverages $(p=0.011)$. The rate of smokers aware of this ban was higher than the rate of non-smokers who were aware. This might have resulted from the fact that smokers were more interested in the ban and encountered the law regarding the same more often.

Workers/business owners who smoked were of the opinion that the law violated their right to smoke; however, they also agreed with the opinion that it protected the right to clean air and health of workers. The thoughts of smoking and non-smoking clients were similar. In a study conducted in pub workers in Argentina, the approval rate of the law is high among smoking and non-smoking workers (12). Smoking clients and workers think that the positive effect of this law on people's behaviors will be limited, while non-smokers are of the opinion that implementing the law will protect the health of workers and rights of non-smokers and support smoking cessation. It is believed that the effect of the law will occur with public acceptance over time, and it is important to be careful for preventing the spread of negative opinions.

The rate of people who approve of the law in various environments is higher among non-smokers than among smokers. In the study, this was particularly apparent in restaurants serving alcoholic beverages. This might have resulted from the fact that this study was conducted in these businesses, and people encountered the defined situation while collecting the data. In addition, the fact that workers spend all day in these businesses and the law puts them in a difficult situation can pose an obstacle for their approval of the law.

During the visit to 27 of 119 cafes, it was observed that there were people who were smoking. It was remarkable that infringement cases were particularly observed in areas separated with glass walls in these businesses. This result shows that people do not exactly obey the legal regulations in the places where smoking is forbidden. In order to increase the obedience of the law, Provincial Councils for Tobacco Control and inspection teams should increase the frequency of their controls $(7,8,13,14)$.

This study has strengths and limitations. This research conducted in the businesses serving alcoholic beverages in the district of Kızılay in 
Ankara is important for determining the rate of awareness of the law. Both client and worker profiles were evaluated in the study, and evidence on workers' exposure to tobacco was obtained. Moreover, the rate of smoking in this group was found to be higher than in the general public studies. On the other hand, the results of the study should be evaluated carefully considering that only a part of the city center was included in the sampling, and the people evaluated in the study were relatively young; hence, these results should not be generalized for all societies. The study in which the attitudes of businesses serving alcoholic beverages were analyzed emphasizes the importance of the intervention toward the coexistence of alcohol and tobacco.

Tobacco addiction is an individualistic reality; however, it should be considered as a public health issue while implementing an intervention. Therefore, in addition to individualistic approaches, the law should be accepted by the public for solving the problem of tobacco addiction, and implementations should be adopted. The factors affecting the tobacco use include norms and attitudes toward smoking in the society, smoking behavior, messages given against smoking, accessibility to tobacco products, and tobacco politics of the country; these factors come together and influence the rate of smoking. In order to decrease the rates of tobacco use and the health problems associated with it, the implementation of tobacco control regulations should be inspected regularly and the society should conform to the rules.

\section{CONCLUSION}

In this study, it was revealed that tobacco and tobacco products were used among workers more frequently, and these workers approve the law. For increasing the obedience toward the law, particularly in businesses serving alcoholic beverages, inspections should be performed regularly.

Ethics Committee Approval: According to the ethics committee recommendations administrative approval was taken from the governorship of Ankara.

Informed Consent: The oral consent was given by the volunteers.

Peer-review: Externally peer-reviewed.

Author contributions: Concept - H.Ö., N.B.; Design H.Ö., N.B.; Supervision H.Ö., B.K.B.; Resource - H.D., B.K., M.C., B.B., T.A., S.T., M.H.B.; Data Collection and/or Processing - B.K.B.; Analysis and/or Interpretation - H.Ö., N.B., S.A., B.K.B.; Literature Search - B.K.B.; Writing - H.Ö., B.K.B..; Critical Reviews - N.B., H.Ö.
Conflict of Interest: No conflict of interest was declared by the authors.

Financial Disclosure: The authors declared that this study has received no financial support.

\section{REFERENCES}

1. World Health Organization (WHO). The Tobacco Atlas, Available from:01.06.2012 URL: http://www.who.int/tobacco/statistics/tobacco_ atlas/en/.

2. WHO Report on the Global Tobacco Epidemic, 2008: The MPOWER Package. Geneva, World Health Organization, 2008. Available from: 15.06.2012 URL: http://www.who.int/tobacco/mpower/2008/en/index.html.

3. Özcebe H, Bilir N, Aslan D. Türkiye'de Sigara İçilmeyen Kamusal Alanların ve İşyerlerinin Genişletilmesi, Sigara Karşııı Politika ve Uygulamaların Değerlendirmesi. Halk Sağlığı Uzmanları Derneği. March 2011. Ss: 10-16.

4. Bilir N, Aslan D. Dünya`da, Türkiye`de ve Hacettepe`de tütün kontrolü çalışmaları. Hacettepe Tıp Dergisi 2005; 36: 75-9.

5. Bilir N, Özcebe H, Ergüder T, Mauer-Stender K. Tobacco control in Turkey: Story of Commitment and Leadership. WHO: Europe. 2012. p. 59.

6. Özcebe H, Küçük Biçer B, Evran AÇ, Matola BW, Kiraz S, Kaplan YG. Türkiyesnin Kapsamlı Tütün Kontrol Yasasından Iki Sene Sonra Kahvehane Müşterilerinin Görüşleri (Ankara, 2011). Turk Toraks Derg 2013; 14: 11-8.

7. T.C. Temel Sağlık Hizmetleri Genel Müdürlüğü. Küresel Yetişkin Tütün Araştırması Türkiye Raporu 2010. Anıl Matbacılık, Yayın No:803, 2010: 37 75.

8. Küresel Yetişkin Tütün Kullanımı Araştırması, Available from: Eylül 2012 URL: http://www.tuik.gov.tr/PreHaberBultenleri.do?id=13142.

9. Khabour OF, Alzoubi KH, Eissenberg T, Mehrotra P, Azab M, Carroll MV, et al. Waterpipe tobacco and cigarette smoking among university students in Jordan. Int J Tuberc Lung Dis 2012; 16: 986-92. [CrossRef]

10. Butler KM, Rayens MK, Hahn EJ, Adkins SM, Staten RR. Smoke-free policy and alcohol use among undergraduate college students. Public Health Nurs 2012; 29: 256-65. [CrossRef]

11. T.C. Sağlık Bakanlığı. GATS 2008 Küresel Yetişkin Tütün Araştırması Türkiye Raporu. Ankara, 2010 (Publication No. 803).

12. Schoj V, Alderete M, Ruiz E, Hasdeu S, Linetzky B, Ferrante D. The impact of a $100 \%$ smoke-free law on the health of hospitality workers from the city of Neuquén, Argentina. Tob Control 2010; 19: 134-7. [CrossRef]

13. Fong GT, Hyland A, Borland R, Hammond D, Hastings G, McNeill A, et al. Reductions in tobacco smoke pollution and increases in support for smoke-free public places following the implementation of comprehensive smokefree workplace legislation in the Republic of Ireland: findings from the ITC Ireland/UK Survey. Tob Control 2006; 15: iii51-8. [CrossRef]

14. Thrasher JF, Pérez-Hernández R, Swayampakala K, Arillo-Santillán E, Bottai M. Policy support, norms, and secondhand smoke exposure before and after implementation of a comprehensive smoke-free law in Mexico city. Am J Public Health 2010; 100: 1789-98. [CrossRef] 